\title{
Gugatan Sederhana sebagai Terobosan Mahkamah Agung dalam Menyelesaikan Penumpukan Perkara di Pengadilan dan Permasalahannya
}

\author{
Arman Tjoneng \\ Faculty of Law, Maranatha Christian University, Indonesia \\ armantjoneng@yahoo.com
}

Submitted: 2017-03-09; Reviewed: 2017-05-05; Accepted: 2017-06-06

\begin{abstract}
Supreme Court Regulation Number 2 of 2015 on Procedure of Small Claim Court is a good step of Supreme Court to realize dispute settlement acoording to principle of fast, simple and light-cost. At first, this regulation enable people to settle their dispute faster than what previous regulation set, but in fact, since the establishment of this regulation in August 7, 2015, the benefit still not at full. This article examine the challenge or obstacle in implementing Supreme Court Regulation Number 2 of 2015. The result show that the reluctance of people to use small claim court mechanism is an obligation that claimer and defendant legally domiciled in same place. Single judge in small claim court also becomes the reason aside from it is not required to use this mechanism.
\end{abstract}

Keywords: cumulation of cases; small claim court; Supreme Court

\section{PENDAHULUAN}

Sengketa dapat terjadi pada siapa saja dan dimana saja. Sengketa dapat terjadi antara individu dengan individu, antara individu dengan kelompok, antara kelompok dengan kelompok, antara perusahaan dengan perusahaan, antara perusahaan dengan negara, antara negara satu dengan yang lainnya, dan sebagainya. Dengan kata lain, sengketa dapat bersifat publik maupun bersifat keperdataan dan dapat terjadi baik dalam lingkup local nasional maupun internasional. Sengketa adalah suatu situasi dimana ada pihak yang merasa dirugikan oleh pihak lain, yang kemudian pihak tersebut menyampaikan ketidakpuasan ini kepada pihak kedua. Jika situasi menunjukkan perbedaan pendapat, maka terjadi lah apa yang dinamakan dengan sengketa.

Dalam konteks hukum khususnya hukum kontrak, yang dimaksud dengan sengketa adalah perselisihan yang terjadi antara para pihak karena adanya pelanggaran terhadap kesepakatan yang telah dituangkan dalam suatu kontrak, 
baik sebagian maupun keseluruhan Dengan kata lain telah terjadi wanprestasi oleh pihak pihak atau salah satu pihak.

Beberapa penyebab timbulnya sengketa di masyarakat dapat dilihat dari beberapa teori yang dikemukakan beberapa ahli, yaitu:

a. Teori hubungan masyarakat

Teori hubungan masyarakat, menitikberatkan adanya

ketidakpercayaan dan rivalisasi

kelompok dalam masyarakat. Para penganut teori ini memberikan solusi solusi terhadap konflik- konflik yang timbul dengan cara peningkatan komunikasi dan saling pengertian antara kelompok- kelompok yang mengalami konflik, serta pengembangan toleransi agar masyarakat lebih bisa saling menerima keberagaman dalam masyarakat. ${ }^{1}$

\section{b. Teori negosiasi prinsip}

Teori negosiasi prinsip menjelaskan bahwa konflik terjadi karena adanya perbedaan-perbedaan diantara para pihak. Para penganjur teori ini berpendapat bahwa agar sebuah konflik dapat diselesaikan, maka pelaku harus mampu memisahkan perasaan pribadinya dengan masalah-masalah dan mampu melakukan negosiasi berdasarkan kepentingan dan bukan pada posisi yang sudah tetap. ${ }^{2}$

c. Teori identitas

Teori ini menjelaskan bahwa konflik terjadi karena sekelompok orang merasa identitasnya terancam oleh pihak lain. Penganut teori identitas mengusulkan penyelesaian konflik karena identitas yang terancam dilakukan melalui fasilitasi lokakarya dan dialog antara wakil-wakil kelompok yang mengalami konflik dengan tujuan mengidentifikasikan ancaman-ancaman dan kekhawatiran yang mereka rasakan serta membangun empati dan rekonsiliasi. Tujuan akhirnya adalah pencapaian kesepakatan bersama yang mengakui identitas pokok semua pihak. ${ }^{3}$

d. Teori kesalahpahaman antar budaya Teori kesalahpahaman antar budaya menjelaskan bahwa konflik terjadi karena ketidakcocokan dalam berkomunikasi diantara orang-orang dari latar belakang budaya yang berbeda. Untuk itu, diperlukan dialog antara orang-orang yang mengalami konflik guna mengenal dan memahami budaya masyarakat lainnya, mengurangi stereotype yang mereka miliki terhadap pihak lain. ${ }^{4}$

e. Teori transformasi

Teori ini menjelaskan bahwa konflik dapat terjadi karena adanya masalah-masalah ketidaksetaraan dan ketidakadilan serta kesenjangan yang terwujud dalam berbagai aspek kehidupan masyarakat baik sosial, ekonomi maupun politik. Penganut teori ini berpendapat bahwa penyelesaian konflik dapat dilakukan melalui beberapa upaya seperti

\footnotetext{
${ }^{1}$ Takdir Rahmadi, Mediasi, Penyelesaian Sengketa Melalui Pendekatan Mufakat, Jakarta: Rajawali Press, 2011, hlm. 8
}

\footnotetext{
${ }^{2}$ Ibid.

${ }^{3}$ Ibid, hlm. 9

4 Ibid.
} 
perubahan struktur dan kerangka kerja yang menyebabkan ketidaksetaraan, peningkatan hubungan, dan sikap jangka panjang para pihak yang mengalami konflik, serta pengembangan proses- proses dan sistem untuk mewujudkan pemberdayaan, keadilan, rekonsiliasi dan pengakuan keberadaan masingmasing. ${ }^{5}$

f. Teori kebutuhan atau kepentingan manusia

Pada intinya, teori ini mengungkapkan bahwa konflik dapat terjadi karena kebutuhan atau kepentingan manusia tidak dapat terpenuhi/terhalangi atau merasa dihalangi oleh orang/pihak lain. Kebutuhan dan kepentingan manusia dapat dibedakan menjadi tiga jenis yaitu substantif, prosedural, dan psikologis. Kepentingan substantif (substantive) berkaitan dengan kebutuhan manusia yang berhubungan dengan kebendaan seperti uang, sandang, pangan, papan/rumah, dan kekayaan. Kepentingan prosedural (procedural) berkaitan dengan tata dalam pergaulan masyarakat, sedangkan kepentingan psikologis (psychological) berhubungan dengan non-materiil atau bukan kebendaan seperti penghargaan dan empati. ${ }^{6}$

Dalam menyelesaikan sengketa yang ada, maka masyarakat dihadapkan kepada dua pilihan, yaitu menyelesaiakan sengketa melalui jalur non litigasi dan jalur litigasi. Jalur non litigasi atau Alternative Dispute Resolution merupakan penyelesaian sengketa di luar pengadilan yang ditempuh oleh para pihak dan menjadi sangat terkenal sebagai upaya lain yang menekankan kesepakatan diantara pihak kecuali arbitrase yang mekanismenya seperti pengadilan. Adapun mekanisme penyelesaian sengketa melalui non litigasi terdiri atas:

a. Negosiasi.

Negosiasi merupakan komunikasi dua arah yang dirancang untuk mencapai kesepakatan pada saat kedua belah pihak memiliki berbagai kepentingan yang sama maupun yang berbeda. Negosiasi ialah proses tawar menawar untuk mencapai kesepakatan dengan pihak lain melalui proses interaksi, komunikasi yang dinamis dengan tujuan untuk mendapatkan penyelesaian atau jalan keluar dari permasalahan yang sedang dihadapi oleh kedua belah pihak.

\section{b. Mediasi.}

Mediasi pada dasarnya adalah negosiasi yang melibatkan pihak ketiga yang memiliki keahlian mengenai prosedur mediasi yang efektif, dapat membantu dalam situasi konflik untuk mengkoordinasikan aktivitas mereka sehingga dapat lebih efektif dalam proses tawar menawar. Mediasi juga dapat diartikan sebagai upaya penyelesaian sengketa para pihak dengan kesepakatan bersama melalui mediator yang bersikap netral, dan 
tidak membuat keputusan atau kesimpulan bagi para pihak tetapi menunjang fasilitator untuk terlaksananya dialog antar pihak dengan suasana keterbukaan, kejujuran, dan tukar pendapat untuk tercapainya mufakat. ${ }^{7}$

\section{c. Arbitrase}

Pasal 1 ayat (1) UndangUndang Nomor 30 tahun 1999 tentang Arbitrase dan Alternatif Penyelesaian Sengketa menjelaskan bahwa arbitrase (wasit) adalah cara penyelesaian suatu sengketa perdata di luar pengadilan umum yang didasarkan pada perjanjian arbitrase yang dibuat secara tertulis oleh para pihak yang bersengketa. Arbitrase digunakan untuk mengantisipasi perselisihan yang mungkin terjadi maupun yang sedang mengalami perselisihan yang tidak dapat diselesaikan secara negosiasi/konsultasi maupun melalui pihak ketiga serta untuk menghindari penyelesaian sengketa melalui Badan Peradilan yang selama ini dirasakan memerlukan waktu yang lama.

Selain mekanisme di atas, sebenarnya alternatif penyelesaian sengketa juga mengenal beberapa mekanisme, yaitu konsiliasi, pendapat ahli dan tim pencari fakta. Tetapi mekanisme yang diuraikan di atas merupakan mekanisme yang paling sering digunakan dikalangan masyarakat.
Selain melalui mekanisme non litigasi, maka penyelesaian sengketa juga dapat dilakukan melalui jalur litigasi, yaitu meminta bantuan pengadilan untuk menyelesaian sengketa yang ada melalui mekanisme putusan hakim yang bersifat menentukan.

Litigasi merupakan proses penyelesaian sengketa di pengadilan, dimana semua pihak yang bersengketa saling berhadapan satu sama lain untuk mempertahankan hak-haknya di muka pengadilan. Hasil akhir dari suatu penyelesaian sengketa melalui litigasi adalah putusan yang menyatakan win-lose solution $^{8}$

Prosedur dalam jalur litigasi ini sifatnya lebih formal dan teknis, menghasilkan kesepakatan yang bersifat menang kalah, cenderung menimbulkan masalah baru, lambat dalam penyelesaiannya, membutuhkan biaya yang mahal, tidak responsif dan menimbulkan permusuhan diantara para pihak yang bersengketa. Kondisi ini menyebabkan masyarakat mencari alternatif lain yaitu penyelesaian sengketa di luar proses peradilan formal.

Walaupun penggunaan penyelesaian sengketa melalui ADR semakin digandrungi masyarakat, khususnya dunia bisnis, tetapi bagi sebagian masyarakat awam masih memandang penyelesaian sengketa melalui jalur litigasi tetap merupakan penyelesaian sengketa yang utama sehingga konsekuensinya terjadi penumpukan perkara di pengadilan baik di tingkat pengadilan tingkat pertama apalagi di tingkat Mahkamah Agung.

8 Nurnaningsih Amriani, Mediasi, Alternatif Penyelesaian Sengketa Perdata di Pengadilan, Jakarta: Rajawali Press, 2012, hlm. 35.

\footnotetext{
${ }^{7}$ Susanti Adi Nugroho, Mediasi sebagai Alternatif Penyelesaian Sengketa, Jakarta: Talaga Ilmu Indonesia, 2009, hlm. 21.
} 
Penumpukan perkara di Mahkamah Agung mencapai \pm 30 ribu berkas perkara dan diperiksa oleh 49 orang Hakim Agung sehingga banyak banyak Putusan Mahkamah Agung yang terkesan "seadanya" tanpa didukung oleh pertimbangan hukum yang komprehensif. Hal ini disebabkan oleh tingginya work load para Hakim Agung kita sehingga para Hakim Agung kurang fokus dalam memeriksa setiap perkara. Secara logika, hal tersebut tentunya akan mempengaruhi kualitas putusan dari Mahkamah Agung itu sendiri.

Di dalam prakteknya, waktu persidangan untuk memeriksa gugatan di

9 Sebelum adanya Surat Edaran (SEMA) No. 6 tahun 1992, yang menegaskan bahwa pemeriksaan perkara (perdata) pada semua tingkat peradilan "wajib" diselesaikan dalam waktu paling lama 6 bulan, pemeriksaan gugatan di tingkat pertama terkadang memakan waktu yang lama bahkan sampai berbulan-bulan dan tidak ada kepastian atas waktu yang diperlukan untuk memutuskan perkara perdata. Hal ini menjadi salah satu "amunisi" dari pihak yang berada di posisi lemah untuk sengaja mengulur-ulur waktu.

${ }^{10}$ Gugatan Sederhana yang diterapkan di Indonesia melalui Perma No. 2 Tahun 2016 dapat dikatakan terinspirasi dari Small Claim Court yang pertama di Amerika Serikat dikembangkan pada awal abad kedua puluh karena proses formal peradilan sipil yang begitu kompleks, rumit, dan mahal yang tidak dapat digunakan oleh sebagian besar orang yang memiliki penghasilan kecil. Small Claim Court merupakan mekanisme penyelesaian sengketa melalui pengadilan (litigasi) dengan prosedur yang terpisah (berbeda) dari prosedur pengadilan biasa, karenanya dikatakan juga sebagai pengadilan informal untuk menyelesaikan gugatan perdata dengan nilai gugatan yang kecil (relatif). Model ini awalnya diadopsi di Amerika Serikat yang meliputi lima komponen utama: a). pengurangan biaya pengadilan $b$ ). penyederhanaan proses permohonan c). Prosedur percobaan sebagian besar diserahkan kepada kebijaksanaan hakim pengadilan, dan aturan formal dari bukti yang telah diseleksi. d). Hakim dan panitera pengadilan yang diharapkan dapat
Pengadilan Tingkat pertama bisa memakan waktu \pm 6 bulan. ${ }^{9}$ Waktu ini belum termasuk pemeriksaan Banding ( \pm 1 tahun) dan Kasasi ( \pm 2-3 tahun). Hal ini belum juga dihitung dengan lamanya proses eksekusi yang berbelit-belit. Penerapan asas peradilan cepat, sederhana dan biaya murah "hanyalah" slogan belaka tanpa adanya realisasi nyata. Inilah yang harus dihadapi oleh masyarakat pencari keadilan.

Menghadapi permasalahan diatas, maka ada terobosan yang dilakukan oleh Mahkamah Agung untuk masyarakat pencari keadilan berupa GUGATAN SEDERHANA $^{10}$ yang diperkuat melalui Peraturan Mahkamah Agung (PERMA)

membantu berperkara baik dalam persiapan percobaan dan di pengadilan sehingga perwakilan oleh pengacara akan sebagian besar tidak diperlukan. e). Hakim diberi kekuatan untuk memutuskan pembayaran angsuran secara langsung. (lihat Steven Weller, John C Ruhnka, and John A Martin, "American Small Claim Courts," in Small Claim Courts: A Comparative Study edited by Chiristopher J Whelan, Oxford: Clarendom Press, 1990, hlm. 5)

Sengketa-sengketa yang dapat diajukan ke Small Claim Court adalah kasus perdata seperti klaim yang berkaitan dengan: a). Utang piutang berdasarkan perjanjian: rekening yang belum dibayar untuk barang atau jasa yang dijual dan dikirimkan, pinjaman yang belum dibayar, sewa yang belum dibayar, dan upah yang belum dibayar; b). Klaim untuk: kerusakan properti, pengembalian properti, cedera akibat perbuatan, dan pelanggaran kontrak.

Beberapa kasus perdata tidak dapat diajukan ke Small Claim Court, seperti misalnya: perbedaan pendapat tentang real properti, pengembalian kepemilikan real properti, penggusuran, klaim terhadap pemerintah, tindakan untuk menyita atau menegakkan hukum, klaim yang timbul dari malpraktek professional (misalnya, dugaan malpraktik oleh dokter, dokter gigi atau pengacara), klaim untuk tunjangan perkawinan, klaim yang 
No. 2 Tahun 2015 tentang Tata Cara Penyelesaian Gugatan Sederhana (selanjutnya disebut Perma No. 2 Tahun 2015).

Kalau dilihat secara teknis, Gugatan Sederhana merupakan terobosan yang inovativ dalam mewujudkan asas peradilan cepat, murah dan sederhana. Tetapi disisi lain, Gugatan Sederhana dengan segala kelebihan dan kekurangan belumlah menjadi sebuah primadona bagi masyarakat pencari keadilan khususnya masyarakat yang tidak mampu. Hal ini terbukti dari masih minimnya penggunaan Gugatan Sederhana di beberapa Pengadilan Negeri. Hal ini menjadi sebuah hal yang patut di teliti.

\section{PEMBAHASAN}

Mekanisme Pengajuan Gugatan Sederhana Berdasarkan Perma No. 2 Tahun 2016 Dilihat dari Asas Sederhana, Cepat dan Biaya Ringan

Gugatan Sederhana adalah termasuk dalam kewenangan atau ruang lingkup dalam peradilan umum. Tidak semua perkara dapat diselesaikan dengan gugatan sederhana. Gugatan Perdata yang dapat dikategorikan sebagai Gugatan Sederhana sebagaimana Pasal 3 dan Pasal 4 Perma No. 2 Tahun 2015 adalah :

1. Sengketa cidera janji/wanprestasi dan atau Gugatan Perbuatan melawan Hukum yang nilai gugatan materil maksimal 200 juta;

2. Bukan perkara yang masuk dalam kompetensi Pengadilan Khusus;

3. Bukan sengketa hak atas tanah;

timbul dari pengesahan hakim. (Lihat Sioux Falls, Business Journal a Gannett Company, Displaying 100 of 30,566 Small Claims Court Judgment, 2006).
4. Penggugat dan Tergugat masingmasing tidak lebih dari satu, kecuali memiliki kepentingan hukum yang sama;

5. Tempat tinggal Tergugat harus diketahui;

6. Penggugat dan Tergugat harus berdomisili di Daerah Hukum Pengadilan yang sama.

Dalam pengajuan Gugatan Sederhana, dibagi menjadi 4 (empat) tahapan penting, yaitu:

\section{Tahap Pendahuluan}

Dalam tahap ini, terdiri dari:

\section{a. Pendaftaran}

Gugatan Sederhana diajukan kepada bagian Kepaniteraan Muda Perdata dengan cara mengisi blanko yang telah disediakan oleh petugas serta melampirkan bukti surat yang sudah dilegalisir. Hal ini berbeda dengan Gugatan Biasa dimana Penggugat harus membuat Gugatan pada umumnya yang berisi tentang aspek hukumnya. Dalam Gugatan Sederhana, Penggugat cukup mengisi blanko yang disediakan dengan menguraikan fakta dan bukti saja.

\section{b. Pemeriksaan Kelengkapan Gugatan Sederhana}

Panitera memeriksa berkas dimaksud apakah termasuk 
kedalam ruang lingkup Gugatan Sederhana sebagaimana yang tercantum dalam Pasal 3 dan Pasal 4 Perma. Jika dinilai bahwa perkaranya tidak termasuk kedalam ruang lingkup Gugatan Sederhana, maka berkas dimaksud dikembalikan kepada Penggugat, tapi bila dinilai ternyata sesuai dengan ruang lingkup Gugatan Sederhana, maka gugatan dicatat dalam buku register khusus untuk itu, yang sebelumnya Penggugat wajib membayar panjar biaya perkara, kecuali perkara probono.

\section{c. Penetapan Hakim dan Penunjukan Panitera} Pengganti

Penetapan Hakim Tunggal dilakukan oleh Ketua Pengadilan Negeri, dan penetepan Panitera Pengganti dilakukan oleh Panitera.

\section{d. Pemeriksaan Pendahuluan oleh Hakim Tunggal}

Hakim Tunggal yang ditunjuk oleh Ketua Pengadilan memeriksa materi Gugatan Sederhana (apakah memenuhi syarat Pasal 3 dan dan Pasal 4 Perma) serta menilai sederhana atau tidaknya pembuktian gugatan dimaksud. Jika Hakim Tunggal menilai, gugatan bukan Gugatan Sederhana, maka Hakim mengeluarkan penetapan yang isinya menyatakan gugatan bukan

Gugatan Sederhana dan

Panitera mencoret perkara tersebut dari register perkara serta memerintahkan pengembalian sisa biaya perkara kepada penggugat. Terhadap Penetapan ini tidak ada upaya hukum. Tapi, jika Hakim Tunggal menilai gugatan adalah gugatan sederhana maka Hakim Tunggal menetapkan hari sidang pertama.

\section{Tahap Pemeriksaan Pokok Perkara}

Dalam tahap ini, terdiri dari:

a. Pemanggilan dan Kehadiran Para Pihak

Jika penggugat tidak hadir pada sidang pertama tanpa alasan yang sah, maka gugatan dinyatakan gugur. Jika tergugat tidak hadir pada sidang pertama, maka dilakukan pemanggilan kedua. Jika panggilan kedua tidak hadir, maka diputus secara verstek. (terhadap putusan verstek, maka dapat diajukan verzet). Jika tergugat pada sidang pertama hadir dan pada hari sidang selanjutnya tidak hadir tanpa alasan yang sah, maka diadili secara Contradictoir.

\section{b. Perdamaian}

Pada sidang pertama Hakim Tunggal wajib mengupayakan perdamaian (tidak memakai proses mediasi sebagaimana 
yang diatur dalam Perma 1

Tahun 2016 tentang Prosedur

Mediasi di Pengadilan karena dalam Perma tersebut ditegaskan bahwa Gugatan Sederhana tidak termasuk ke dalam ruang lingkup Perma 1 Tahun 2016 tentang Prosedur Mediasi di Pengadilan). Jika tercapai perdamaian, maka kesepakatan perdamaian tersebut akan dikukuhkan menjadi Akta Perdamaian yang berkekuatan hukum tetap (Inkracht van Gewijsde) dan tidak ada upaya hukum untuk Akta Perdamaian ini. Jika tidak terjadi Perdamaian, maka akan dilanjutkan dengan pemeriksaan pokok perkara.

\section{c. Pemeriksaan Pokok Perkara}

Pemeriksaan pokok perkara ditandai dengan pembacaan "gugatan" Penggugat dilanjutkan dengan jawaban dari Tergugat. Berbeda dengan gugatan biasa, pada Gugatan Sederhana, tidak dapat diajukan Tuntutan provisi, Eksepsi, Rekonvensi, Intervensi, Replik, Duplik, dan Kesimpulan. Gugatan Sederhana langsung masuk pada proses pembuktian. Gugatan yang diakui dan / tidak dibantah oleh Tergugat maka tidak perlu dilakukan pembuktian, tetapi sebaliknya apabila ada bantahan dari Tergugat, maka pemeriksaan pembuktian berdasarkan Hukum Acara.

\section{d. Putusan}

Perkara Gugatan Sederhana wajib diselesaikan Hakim Tunggal paling lama 25 (dua puluh lima) hari sejak hari sidang pertama dilakukan. Putusan yang dibacakan pada sidang terbuka untuk umum terdiri dari kepala putusan dengan irah-irah, Identitas para pihak, Uraian singkat duduk perkara, Pertimbangan hukum dan Amar putusan. Terhadap pihak yang tidak terima dengan isi putusan dimaksud, maka Hakim Tunggal menyampaikan upaya hukum yaitu KEBERATAN yang dapat diajukan paling lambat 7 (tujuh) hari setelah putusan diucapkan atau diberitahukan. Hal ini berbeda dengan gugatan biasa dimana bila ada pihak yang tidak setuju dengan isi putusan Pengadilan Negeri, maka bisa mengajukan BANDING ke Pengadilan Tinggi dengan jangka waktu 14 (empat belas) hari setelah putusan diucapkan atau diberitahukan.

\section{Tahap Permohonan Keberatan}

Dalam tahap ini, terdiri dari:

a. Daftar

Permohonan Keberatan

Keberatan diajukan ke Ketua Pengadilan Negeri paling lambat 7 (tujuh) hari setelah putusan dibacakan atau diterima dengan menandatangani Akta Penyataan Keberatan dihadapan Panitera disertai alasan dan 
mengisi blanko Permohonan Keberatan di kepaniteraan. (Bandingkan dengan permohonan Banding yang diajukan ke Ketua Pengadilan Tinggi). Kepaniteraan menerima dan memeriksa kelengkapan berkas Permohonan Keberatan dan disertai dengan Memori Keberatan yang dibuat oleh Pemohon Keberatan. Pemberitahuan Keberatan dan Memori Keberatan disampaikan kepada pihak Termohon Keberatan dalam waktu 3 (tiga) hari sejak Permohonan Keberatan diterima. Pihak Termohon Keberatan menyerahkan Kontra Memori Keberatan kepada Ketua Pengadilan Negeri paling lambat 3 (tiga) hari setelah pemberitahuan Keberatan.

\section{b. Pemeriksaan Keberatan}

Setelah berkas Permohonan Keberatan dinyatakan lengkap , maka Ketua Pengadilan Negeri menetapkan

MAJELIS

HAKIM yang dipimpin oleh Hakim Senior untuk memeriksa dan memutus permohonan Keberatan. Majelis Hakim melakukan pemeriksaan keberatan yang dilakukan hanya atas dasar dari Putusan dan berkas gugatan, Permohonan Keberatan, Memori Keberatan dan Kontra Memori Keberatan. Dalam pemeriksaan Permohonan Keberatan ini,
Majelis Hakim tidak melakukan pemeriksaan tambahan. Hal ini berbeda dengan Banding di Pengadilan Tinggi, dimana Majelis Hakim Pengadilan tinggi sebagai judex factie masih bisa melakukan pemeriksaan tambahan manakala dianggap pemeriksaan di Pengadilan Tingkat Pertama masih ada kekurangan.

\section{c. Putusan Keberatan}

Putusan atas Permohonan Keberatan diucapkan paling lambat 7 (tujuh) hari setelah tanggal penetapan Majelis Hakim oleh Ketua Pengadilan Negeri. Putusan Permohonan Keberatan sama dengan Putusan sebelumnya dan wajib diberitahukan kepada para pihak paling lambat 3 (tiga) hari sejak Putusan Permohonan Keberatan dibuat. Terhadap Putusan Permohonan Keberatan ini tidak dapat dilakukan upaya hukum lainnya seperti Banding, Kasasi dan Peninjauan Kembali Karena Putusan Permohonan Keberatan ini memiliki kekuatan hukum tetap.

\section{Tahap Pelaksanaan Putusan Gugatan Sederhana}

Terhadap putusan terhadap Gugatan Sederhana yang telah berkekuatan hukum tetap, dilaksanakan secara suka rela oleh para pihak. Jika tidak dipatuhi oleh para pihak, maka pelaksanaan 
putusan dilaksanakan berdasarkan

Hukum Acara Perdata, yaitu melalui bantuan Pengadilan Negeri untuk mengeksekusi.

Menurut UU Nomor 48 tahun 2009 tentang Kekuasaan Kehakiman, pada Pasal 2 ayat (4) menyebutkan bahwa peradilan dilakukan dengan sederhana, cepat, dan biaya ringan. Asas sederhana, cepat dan biaya ringan adalah asas peradilan yang paling mendasar dari pelaksanaan dan pelayanan administrasi peradilan yang mengarah pada prinsip dan asas efektif dan efisien.

Asas Sederhana adalah pemeriksaan dan penyelesaian perkara dilakukan dengan cara efesien dan efektif. Sederhana juga dapat dimaknai sebagai suatu proses yang tidak berbelit-belit, tidak rumit, jelas, lugas, non interpretable, mudah dipahami, mudah dilakukan, mudah diterapkan, sistematis, konkrit baik dalam sudut pandang pencari keadilan, maupun dalam sudut pandang penegak hukum yang mempunyai tingkat kualifikasi yang sangat beragam, baik dalam bidang potensi pendidikan yang dimiliki, kondisi sosial ekonomi, budaya dan lain-lain. Namun dalam prakteknya asas sederhana hanya dimaknai sebatas masalah administratif belaka tanpa adanya pemahaman bahwa asas sederhana harus menjadi jiwa dan semangat motivasi penegak hukum yang dilaksanakan secara menyeluruh pada setiap tingkatan dan institusi. Sederhana juga dapat diartikan sebagai acara yang jelas, mudah difahami dan tidak berbelit belit. Makin sedikit dan sederhana formalitas-formalitas yang diwajibkan atau diperlukan dalam beracara di muka pengadilan, akan makin baik. Terlalu banyak formalitas yang sukar difahami, atau peraturan-peraturan yang berwayuh arti (dubieus), sehingga memungkinkan timbulnya pelbagai penafsiran, kurang menjamin adanya kepastian hukum dan menyebabkan keengganan atau ketakutan untuk beracara di muka pengadilan. ${ }^{11}$ Bila dilihat mekanisme Gugatan Sederhana di atas, sangat jelas bahwa terdapat "kesederhanaan" yang signifikan dibandingkan dengan Gugatan Biasa, dimana dalam pengajuan Gugatan Sederhana tidak diperlukan pembuatan gugatan yang "rumit" seperti gugatan biasa, cukup menjabarkan kasus posisi dan buktibukti yang dimiliki yang dituangkan dalam blanko yang disediakan. Tidak perlu memikirkan pengajuan Replik oleh dan Duplik oleh Tergugat, Kesimpulan, serta system pembuktian yang jauh lebih mudah dibandingkan dengan Gugatan Biasa. Gugatan Sederhana tidak mengenal Pemeriksaan Setempat (PS) sebagaimana dalam Gugatan Biasa. Selain itu juga, mekanisme keberatan atas putusan Gugatan Sederhana dibuat sedemikian mungkin sehingga tidak mengenal adanya upaya hukum banding, kasasi dan peninjauan kembali seperti dalam Gugatan Biasa.

Asas Cepat harus dimaknai sebagai upaya strategis untuk menjadikan sistem peradilan sebagai institusi yang dapat menjamin terwujudnya/ tercapainya keadilan dalam penegakan hukum secara cepat oleh pencari keadilan. Bukan hanya asal cepat terselesaikan saja yang

${ }^{11}$ Sudikno Mertokusumo, Hukum Acara Perdata Indonesia, Edisi Keenam, Yogyakarta: Liberty, 2006, hlm.36 
diterapkan tapi pertimbangan yuridis, ketelitian, kecermatan, maupun pertimbangan sosilogis yang menjamin rasa keadilan masyarakat juga diperhatikan. Asas ini meliputi cepat dalam proses, cepat dalam hasil, dan cepat dalam evaluasi terhadap kinerja dan tingkat produktifitas institusi peradilan. Cepat menunjuk pada jalannya peradilan, terlalu banyak formalitas merupakan hambatan bagi jalannya peradilan. Dalam hal ini bukan hanya jalannya peradilan dalam pemeriksaan di muka sidang saja, tetapi juga penyelesaian pada berita acara pemeriksaan di persidangan sampai pada penandatanganan putusan oleh hakim dalam pelaksanaannya. Jalannya persidangan yang cepat akan meningkatkan kewibawaan pengadilan dan menambah kepercayaan masyarakat kepada pengadilan. Bila dilihat mekanisme Gugatan Sederhana, dengan adanya "penyederhanaan" mekanisme maka secara otomatis berpengaruh kepada waktu yang diperlukan untuk menyelesaikan Gugatan Sederhana. ${ }^{12}$

Asas Biaya Ringan adalah biaya perkara yang dapat dijangkau oleh masyarakat. Biaya ringan juga mengandung makna bahwa mencari keadilan melalui lembaga peradilan tidak sekedar orang yang mempunyai harapan akan jaminan keadilan di dalamnya tetapi harus ada jaminan bahwa keadilan tidak mahal, keadilan tidak dapat dimaterialisasikan, dan keadilan yang mandiri serta bebas dari nila-nilai lain yang merusak nilai keadilan itu sendiri.

12 Seperti telah disinggung sebelumnya di atas, bahwa rata-rata waktu yang diperlukan untuk menyelesaikan Gugatan Biasa adalah \pm 6 bulan. Waktu ini belum termasuk pemeriksaan Banding $( \pm$ 1 tahun) dan Kasasi ( \pm 2-3 tahun). Bandingkan
Mekanisme Gugatan Sederhana secara prinsip dibuat sebenarnya untuk membantu masyarakat miskin yang akan mencari keadilan melalui pengadilan tetapi tidak dibebani dengan biaya yang tinggi.

\section{Permasalahan Implementasi Gugatan Sederhana}

Gugatan Sederhana yang dirancang untuk membantu masarakat pencari keadilan serta mengurangi penumpukan perkara di Pengadilan khususnya di Mahkamah Agung memang sangat membantu bagi masyarakat yang membutuhkan. Gugatan Sederhana ini juga tidak wajib diwakili kuasa hukum atau memakai jasa advokat seperti halnya dalam perkara gugatan biasa. Namun, para pihak (penggugat dan tergugat) dengan atau tanpa kuasa hukum wajib hadir langsung ke persidangan. Hal ini menyebabkan Gugatan Sederhana tidak dapat diterapkan ketika tergugat tidak diketahui keberadaannya.

Tetapi persoalan lain timbul manakala terbentur pada masalah domisili dari para pihak. Sesuai dengan Pasal 4 Perma No. Tahun 2015, disebutkan bahwa Penggugat dan Tergugat harus berdomisili di daerah hukum Pengadilan yang sama. Hal inilah yang menjadi permasalahan di lapangan. Banyak para pencari keadilan yang terbentur dengan permasalahan domisili ini sehingga tidak dapat memanfaatkan mekanisme Gugatan Sederhana. Bila ditelaah, alasan domisili Penggugat dan Tergugat haruslah berdomisili hukum di daerah hukum pengadilan yang sama sesuai dengan Pasal 4 Perma No. 2 Tahun 2015

dengan penggunaan Gugatan Sederhana yang memerlukan waktu tidak sampai 2 bulan sudah mendapatkan putusan yang sudah berkekuatan hukum tetap. 
dapat dipahami agar pelaksanaan Gugatan Sederhana ini dapat berjalan dengan cepat sesuai dengan salah asas pengadilan yaitu cepat, sederhana dan murah. Tetapi bila dilihat dari sisi keadilan, maka hal ini belumlah memberikan rasa keadilan bagi masyarakat. Seharusnya masalah domisili ini dapat diantisipasi dengan sebuah gebrakan nyata dimana masalah administrasi tentang Gugatan Sederhana ini diberikan sebuah keistimewaan dan didahulukan dari gugatan biasa sehingga permasalahan panggilan/relas keluar kota yang menjadi kendala dari proses Gugatan Sederhana dapat diantisipasi. Kalau selama ini pemanggilan/relas ke pengadilan lain menggunakan jalur surat menyurat yang memakan waktu lama ( \pm 3 minggu untuk relas luar kota), maka dalam panggilan Gugatan Sederhana dari Pengadilan Negeri tempat Gugatan Sederhana diajukan ke Pengadilan Negeri tempat domisili Tergugat dapat menggunakan $e$-mail (surat elektronik) sehingga tidak memerlukan waktu yang lama. Tetapi hal ini tentunya harus didukung oleh tenaga petugas pengadilan (Juru Sita) yang khusus menangani relas Gugatan Sederhana sehingga permasalahan mengenai domisili tersebut dapat diantisipasi sehingga Gugatan Sederhana dapat menjangkau para pihak yang berbeda domisili.

Disisi lain, pemeriksaan Gugatan Sederhana yang menggunakan jasa Hakim Tunggal dalam memutus perkara Gugatan Sederhana juga merupakan sebuah permasalahan tersendiri mengingat hal ini dapat dipandang sebuah hal yang tidak objektif. Maksud penyusun Perma ini memang baik bahwa dengan diperiksa oleh Hakim Tunggal, maka pemeriksaan Gugatan Sederhana dapat berjalan dengan cepat mengingat permasalahannya yang tidak terlalu rumit dan nilai nominal yang tidak terlalu besar (maksimal Rp. 200.000.000,-). Tetapi ada hal yang mungkin dilupakan oleh penyusun Perma bahwa Gugatan Sederhana adalah pemeriksaan atas adanya sebuah sengketa antara satu pihak dan pihak lainnya (Penggugat dan Tergugat), sehingga sesuai dengan kaidah Hukum Acara Perdata, bahwa pemeriksaan Gugatan tetaplah harus dilakukan oleh Majelis Hakim (3 orang Hakim). Penggunaan Hakim tunggal hanyalah digunakan pada saat memutuskan perkara yang tidak mengandung unsur sengketa, berupa Penetapan Pengadilan seperti Penetapan Perwalian dan Pengampuan dan sebagainya. Bila kita bandingkan dengan gugatan mediasi, yaitu gugatan yang diajukan oleh salah satu pihak yang telah mencapai kesepakatan melalui proses mediasi yang tujuannya hanyalah untuk mengukuhkan kesepakatan perdamaian menjadi akta perdamaian tetap diperiksa dan dikukuhkan oleh Majelis Hakim padahal gugatan tersebut sudah tidak mengandung unsur sengketa karena sudah diselesaikan melalui proses mediasi sebelumnya. Hal ini menjadi sebuah kotradiksi yang harus segera diperbaiki mengingat hal ini bisa membuat penerapan Gugatan Sederhana menjadi tidak optimal.

Permasalahan lainnya yang menurut penulis harus segera dipikirkan solusinya adalah penggunaan Gugatan Sederhana yang belum menjadi sebuah keharusan tetapi masih menjadi sebuah pilihan bagi masyarakat. Hal ini membuat penerapan Gugatan Sederhana belum maksimal karena masyarakat pencari keadilan tidak diharuskan menggunakan Gugatan Sederhana. Beberapa kasus di lapangan 
menunjukan bahwa beberapa kelompok masyarakat lebih menyukai menggunakan jalur Gugatan Biasa dibandingkan menggunakan Gugatan Sederhana walaupun syarat dan ketentuannya sudah memenuhi untuk menggunakan Gugatan Sederhana. Hal ini disebabkan masyarakat lebih "nyaman" menggunakan jalur Gugatan Biasa daripada Gugatan Sederhana. Kalau hal ini dibiarkan terus menerus tanpa adanya terobosan baru yang mewajibkan masyarakat menggunakan mekanisme Gugatan sederhana sesuai dengak syarat dan prosedur yang ada, maka bisa jadi tujuan diterapkan Gugatan Sederhana tidak akan terwujud.

\section{PENUTUP}

Berdasarkan pemaparan diatas dapat disimpulkan bahwa mekanisme Gugatan Sederhana benar-benar menerapkan asas peradilan sederhana, cepat dan biaya ringan. Hal ini dapat dilihat dari mekanismenya yang sangat menunjukan "kesederhanaan", "kecepatan" dan biaya ringan. Asas sederhana, cepat, dan biaya ringan dalam pemeriksaan dan menyelesaian perkara di pengadilan tidak mengesampingkan ketelitian dan kecermatan dalam mencari kebenaran dan keadilan. Apabila asas sederhana, cepat, biaya ringan sebagaimana telah diuraikan di atas menjadi semangat para penegak hukum, maka sistem peradilan yang efektif dan efisien dapat di wujudkan. Pembenahan sistem peradilan akhirnya tidak dapat hanya tergantung dalam pemahaman harfiah dari penegak hukum terhadap asas sederhana, cepat dan biaya ringan saja, namun dari itu semua adalah nurani penegak hukum, pencari keadilan, penguasa, legislatif dan sistem yang membingkai institusi peradilan juga menjadi faktor dominan. Semua faktor itu jika dapat dimaksimalkan bukan tidak mungkin sistem peradilan akan lebih baik lagi dan akan menciptakan peradilan yang bersih, jujur, objektif dan adil.

Namun demikian, ternyata dalam implementasi Gugatan Sederhana di lapangan, terdapat beberapa permasalahan yang harus segera diantisipasi dan diperbaiki, yaitu mengenai kedudukan Penggugat dan Tergugat haruslah satu domisili, penggunaan Hakim Tunggal dalam memeriksa dan memutus Gugatan Sederhana, serta belum diwajibkan penggunaan Gugatan Sederhana bagi masyarakat pencari keadilan yang perkaranya memenuhi persyaratan untuk menggunakan Gugatan Sederhana. Semoga pelaksanaan mekanisme Gugatan Sederhana ini dapat berjalan secara optimal sehingga masyarakat pencari keadilan dapat merasakan keadilan yang dicitacitakan tanpa dihantui dengan slogan "mencari keadilan di pengadilan ibarat menuntut kambing mengorbankan sapi". Semoga........

\section{DAFTAR PUSTAKA}

\section{Buku}

Nurnaningsih Amriani, Mediasi, Alternatif Penyelesaian Sengketa Perdata di Pengadilan, Jakarta: Rajawali Press, 2012

Sioux Falls, Business Journal a Gannett Company, Displaying 100 of 30,566

Small Claims Court Judgment, 2006

Sudikno Mertokusumo, Hukum Acara Perdata Indonesia, Edisi Keenam, Yogyakarta: Liberty, 2006 
Susanti Adi Nugroho, Mediasi sebagai Alternatif Penyelesaian Sengketa, Jakarta: Talaga Ilmu Indonesia, 2009

Steven Weller, John C Ruhnka, and John A Martin, "American Small Claim Courts," in Small Claim Courts: A Comparative Study edited by Chiristopher J Whelan, Oxford: Clarendom Press, 1990

Takdir Rahmadi, Mediasi, Penyelesaian Sengketa Melalui Pendekatan Mufakat, Rajawali Press, Jakarta, 2011;

\section{Peraturan Perundang-undangan}

Undang-Undang Nomor 48 tahun 2009 tentang Kekuasaan Kehakiman

Undang-Undang Nomor 30 tahun 1999 tentang Arbitrase dan Alternatif Penyelesaian Sengketa

Perma No. 1 Tahun 2016 tentang Prosedur Mediasi di Pengadilan;

Perma No. 2 Tahun 2015 tentang Tata Cara Penyelesaian Gugatan Sederhana;

Surat Edaran (SEMA) No. 6 tahun 1992 